\title{
KEANEKARAGAMAN AVIFAUNA DIURNAL PADA KAWASAN MEMPAWAH MANGROVE PARK DAN SEKITARNYA DI DESA PASIR KABUPATEN MEMPAWAH
}

\author{
Diversity Of Avifauna In Mempawah Mangrove Park And Surroundings In Pasir Village \\ Mempawah District
}

\author{
Apik Prabowo, Iswan Dewantara, Hari Prayogo \\ Fakultas Kehutanan Universitas Tanjungpura Pontianak. J1. Daya Nasional Pontianak 78124 \\ E-mail: apikprabowo.ap@gmail.com
}

\begin{abstract}
Abstrak
Avifauna is one of the animals that is easily found in various places, and is one indicator of environmental quality. Avifauna has the ability to spread seeds, help pollinate, natural predators of other animals, and others. This study aims to record the diversity of diurnal avifauna in area Mempawah Mangrove Park and its surroundings in Pasir Village Mempawah Hilir Subdistrict, Mempawah district. The research method used the Point count method, whose observation points are obtained by Purposive sampling, carried out on 9 July-9 August 2018. The results of observations were 35 species of avifauna consisting of 24 families which were divided into three habitats, in the mangrove habitat there were 18 species and 15 families, mixed garden contained 22 species and 18 families, and rice field contained 17 species and 11 families. The dominance index in the mangrove habitat is $C=0.40$, mixed garden is $C=0.10$ and rice is $C=0.13$, indicates that no species dominates the other species, meaning the role of the avifauna species found in all three same habitat. Diversity index shows that mixed garden habitat has a higher species diversity with $(\bar{H})=2.66$, mangrove habitat is $(\bar{H})=2.43$ and a rice field habitat is $(\bar{H})=2.40$, indicates that the three habitats have diversity with moderately criteria. Evenness index in mangrove habitat is $(E)=0.84$, in mixed garden habitat is $(E)=$ 0.85 and a rice field habitat is $(E)=0.85$, indicates the three habitats the abundance includes evenly distributed or included in a stable community. The highest similarity index of avifauna species is between mangrove habitat and mixed garden with a percentage of $53.58 \%$, rice field habitat with a garden with a percentage of $53.19 \%$, and mangrove habitat with rice fields with a percentage of $38.49 \%$. The highest similarity was between.
\end{abstract}

Keywords: Avifauna, Diversity, Mempawah Mangrove Park.

\section{PENDAHULUAN}

Satwa avifauna merupakan salah satu satwa yang mudah dijumpai diberbagai tempat, dan mempunyai posisi yang penting sebagai salah satu kekayaan satwa di Indonesia. Jenisnya sangat beranekaragam dan masing-masing jenis memiliki nilai keindahan tersendiri (Wisnubudi 2009). Avifauna merupakan salah satu satwa yang terdapat hampir di setiap tempat, tetapi untuk hidupnya memerlukan syarat-syarat tertentu yaitu adanya kondisi habitat yang cocok, baik, serta aman dari segala macam gangguan (Syafrudin 2011). Penyebaran suatu jenis avifauna disesuaikan dengan kemampuan pergerakannya atau kondisi lingkungan seperti pengaruh luas kawasan, ketinggian tempat dan letak geografis. Faktor yang menentukan keberadaan avifauna 
diantaranya meliputi ketersediaan makanan, tempat untuk istirahat, bermain, berkembangbiak, bersarang, bertengger dan berlindung. Kehadiran suatu avifauna pada suatu habitat merupakan hasil pemilihan karena habitat tersebut sesuai untuk kehidupannya. Kawasan Mempawah Mangrove Park dan sekitarnya di Desa Pasir merupakan salah satu kawasan yang menjadi habitat avifauna dalam proses perkembangbiakannya.

Penelitian mengenai avifauna penting dilakukan, karena jika suatu areal tersebut memiliki kelimpahan avifauna yang tinggi, maka bisa menjadi salah satu indikator bahwa kondisi lingkungan itu baik. Hal ini dikarenakan avifauna memiliki kemampuan untuk menyebarkan biji, membantu penyerbukan, predator alami satwa lain, dan lain-lain. Avifauna dalam melakukan aktivitasnya membutuhkan habitat yang sesuai. Salah satu habitat yang diduga baik untuk satwa liar avifauna adalah pada kawasan Mempawah Mangrove Park dan sekitarnya di Desa Pasir Kecamatan Mempawah Hilir.

Pengembangan dan perhatian yang dilakukan pada kawasan hutan mangrove dan sekitarnya di MMP yang dapat menciptakan habitat yang baru, diduga akan menambah keanekaragaman jenis avifauna pada kawasan tersebut, karena seperti diketahui bahwa satwa liar avifauna juga merupakan salah satu bagian indikator dalam keseimbangan ekositem. Penelitian mengenai keanekaragaman jenis avifauna diurnal perlu untuk dilakukan, karena di kawasan MMP dan sekitarnya belum pernah dilakukan.
Tujuan dilakukannya penelitian ini adalah untuk mendata keanekaragaman jenis avifauna diurnal yang ada pada kawasan Mempawah Mangrove Park dan sekitarnya di Desa Pasir Kecamatan Mempawah Hilir Kabupaten Mempawah serta memberikan kontribusi dalam ilmu pengetahuan mengenai keanekaragaman jenis avifauna diurnal, khususnya pada kawasan hutan mangrove serta memberikan informasi dan referensi bagi pengembangan seperti melakukan upaya perlindungan dan pelestarian satwa liar avifauna pada kawasan Mempawah Mangrove Park dan sekitarnya.

\section{METODE PENELITIAN}

Penelitian ini dilaksanakan di kawasan Mempawah Mangrove Park dan sekitarnya yaitu di tiga kondisi habitat diantaranya habitat mangrove, habitat kebun dan habitat sawah di Desa Pasir Kecamatan Mempawah Hilir Kabupaten Mempawah dengan waktu penelitian dimulai pada bulan Juli - Agustus 2018. Alat dan bahan yang digunakan adalah Peta lokasi, GPS, binokuler, kamera, jam tangan, tally sheet,dan buku panduan pengamatan "Burung-burung di Sumatera, Jawa, Bali, dan Kalimantan" (MacKinnon et al, 2010). Objek penelitian adalah avifauna diurnal yang ada di kawasan Mempawah Mangrove Park dan sekitarnya di habitat mangrove, sawah dan kebun.

Penelitian ini menggunakan metode Point count (titik hitung) (Bibby et al., 2000) yang titiknya ditentukan dengan purposive sampling (secara sengaja). Metode point count digunakan setelah melakukan eksplorasi di tiga habitat 
tersebut yang ada di Mempawah Mangrove Park dan sekitarnya yang dilakukan dalam waktu beberapa hari, sampai benar-benar mendapatkan tempat yang pas sebagai titik pengamatan. Penelitian dilakukan pada saat satwa liar avifauna melakukan aktifitas, yaitu pukul 05.30-09.00 WIB diduga pada saat avifauna mencari makan, dilanjutkan pukul 12.00-13.30 WIB diduga pada saat avifauna istirahat/sedang bermain, dan pada pukul 15.30-17.30 WIB diduga pada saat avifauna ingin kembali ke sarang. Pelaksanaannya adalah dalam suatu kawasan/habitat, dimulai dari pukul 05.30 pada titik pertama yang dilakukan pengamatan selama 20 menit dan dilanjutkan ke titik/tempat pengamatan selanjutnya dengan durasi yang sama. Pengamatan dilakukan dengan 3 kali ulangan, dengan kembali ke titik pertama, dalam waktu yang berbeda, pengamatan dilakukan dengan cara yang sama pada ketiga habitat.

Rute dalam pengamatan pada ketiga habitat yaitu kawasan mangrove, kebun dan sawah mengikuti jalur titik dari hasil eksplorasi ke seluruh kawasan masingmasing habitat. Jarak antar titik satu dengan yang lainnya bersifat dinamis/berubah-ubah tergantung pada kondisi titik yang telah ditentukan sesuai dengan kriteria.

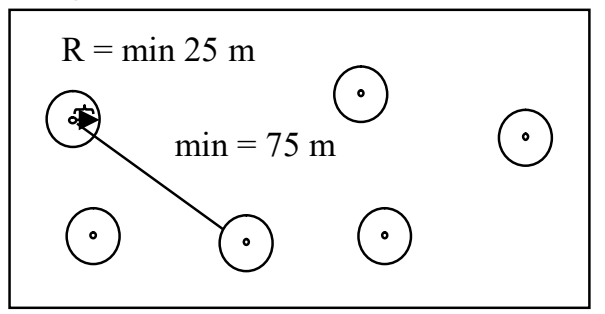

Gambar 1. Titik hitung pada pengamatan (Calculating point on observation)

\section{Analisis Data}

Keanekaragaman jenis avifauna pada setiap lokasi penelitian dihitung menggunakan beberapa analisis, yaitu sebagai berikut :

a. Indeks Dominansi (Simpson's Indeks)

$\mathrm{C}=\sum\left(\frac{n i}{N}\right)^{2}$

Ket :

$\mathrm{ni}=$ Jumlah individu suatu jenis

$\mathrm{N}=$ Jumlah individu dari seluruh jenis

Kriteria dominansi yaitu :

Indeks dominansi bernilai antara 0 1, jika nilai $\mathrm{C}$ mendekati 0 atau semakin kecil maka tidak terdapat jenis yang mendominasi jenis lainnya sedangkan jika nilai $\mathrm{C}$ mendekati angka 1 atau semakin besar, maka terdapat jenis yang mendominasi jenis lainnya.

b. Indeks Keanekaragaman Jenis

$\bar{H}=-\Sigma \mathrm{Pi} \ln \mathrm{Pi}$, dimana $\mathrm{Pi}=\left(\frac{n i}{N}\right)$

Ket :

$\bar{H}=$ Indeks keanekaragaman Shannon-Wiener

$\mathrm{Pi}=$ Proporsi individu suatu spesies $\left(n_{i}\right)$ terhadap keseluruhan individu yang dijumpai $(\mathrm{N})$

In = Logaritma natural

c. Indeks Kemerataan

$\mathbf{E}=\frac{\bar{H}}{\ln S}$

Ket :

$\bar{H}=$ Indeks Keanekaragaman Shannon-Wiener

$\ln =$ Logaritma natural

$\mathrm{S}=$ Jumlah jenis

d. Tingkat pertemuan

Data tingkat pertemuan dapat dibagi menjadi kategori ordinal mentah kelimpahan (misalnya berlimpah, umum, sering, jarang dan langka).

Tingkat pertemuan:

Jumlah individu tiap jenis avifauna

Jumlah jam pengamatan 
JURNAL HUTAN LESTARI (2019)

Vol. 7 (1) : 316 - 326

Tabel 1. Kriteria tingkat pertemuan (Meeting level criteria)

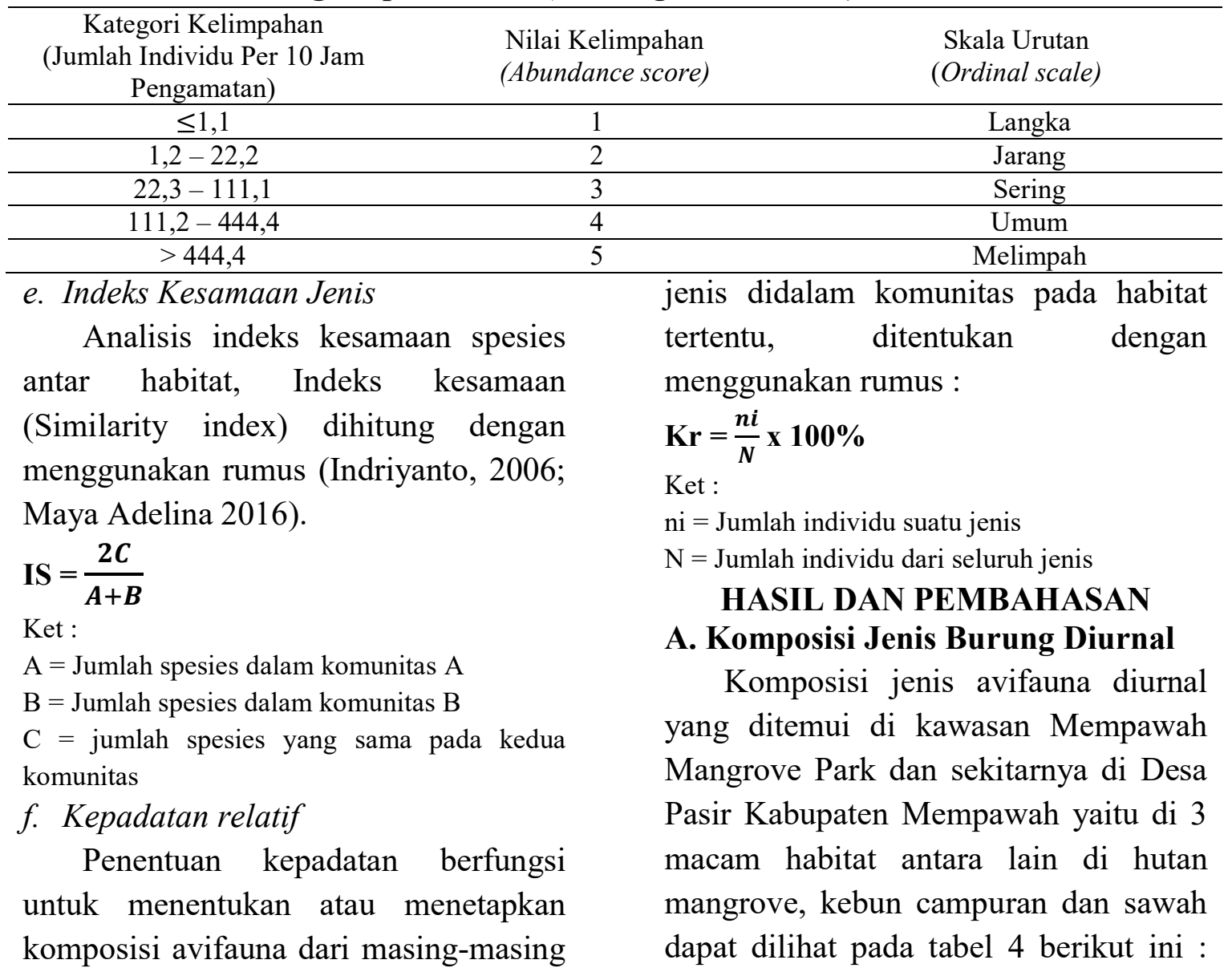


JURNAL HUTAN LESTARI (2019)

Vol. 7 (1) : $316-326$

Tabel 2. Daftar jenis avifauna yang ditemukan secara kesluruhan di kawasan Mempawah Mangrove Park dan sekitarnya. (List species of avifauna found in totality in area Mempawah Mangrove Park and its surroundings.)

\begin{tabular}{|c|c|c|c|c|c|c|c|c|c|c|}
\hline \multirow{2}{*}{ No } & \multirow{2}{*}{ Family } & \multirow{2}{*}{ Nama ilmiah } & \multirow{2}{*}{ English name } & \multirow{2}{*}{ Nama lokal } & \multicolumn{3}{|c|}{ Lokasi } & \multicolumn{3}{|c|}{ Status Perlindungan } \\
\hline & & & & & KBN & MNG & KBN & $\mathbf{P P}$ & IUCN & CITES \\
\hline 1 & Accipitridae & $\begin{array}{l}\text { Haliaeetus } \\
\text { leucogaster }\end{array}$ & $\begin{array}{l}\text { White-bellied sea- } \\
\text { eagle }\end{array}$ & Burung elang putih & - & - & 1 & $\mathrm{AB}$ & $\mathrm{LC}$ & II \\
\hline 2 & Accipitridae & $\begin{array}{l}\text { Haliastur } \\
\text { indus }\end{array}$ & Brahminy kite & Burung elang & 4 & 1 & 2 & $\mathrm{AB}$ & LC & II \\
\hline 3 & Aegithinidae & $\begin{array}{l}\text { Aegithina } \\
\text { tiphia }\end{array}$ & Common lora & Sirtu & 8 & 2 & - & & $\mathrm{LC}$ & \\
\hline 4 & Alcedinidae & $\begin{array}{l}\text { Todirhamphu } \\
\text { s chloris }\end{array}$ & Collared kingfisher & Burung raja udang & 3 & 3 & - & A & $\mathrm{LC}$ & \\
\hline 5 & Ardeidae & $\begin{array}{l}\text { Ardeola } \\
\text { speciosa }\end{array}$ & Javan pond heron & Burung bangau & 8 & - & - & B & $\mathrm{LC}$ & \\
\hline 6 & Ardeidae & $\begin{array}{l}\text { Ixobrychus } \\
\text { cinnamomeus }\end{array}$ & Cinnamon bittern & Keroa becing & - & - & 2 & & $\mathrm{LC}$ & \\
\hline 7 & Campephagidae & Lalage nigra & pied triller & Burung kapas putih & 3 & - & - & & $\mathrm{LC}$ & \\
\hline 8 & Ciconiidae & Bubulcus ibis & Cattle egret & Burung bangau & 3 & - & - & A & $\mathrm{LC}$ & \\
\hline 9 & Cisticolidae & $\begin{array}{l}\text { Prinia } \\
\text { inornata }\end{array}$ & Plain prinia & Burung ceriak padi & - & 3 & 3 & & $\mathrm{LC}$ & \\
\hline 10 & Columbidae & $\begin{array}{l}\text { Streptopelia } \\
\text { chinensis }\end{array}$ & $\begin{array}{l}\text { Eastern Spotted } \\
\text { Dove }\end{array}$ & Tekukur & - & 7 & 3 & & LC & \\
\hline 11 & Columbidae & Treron olax & little green-pigeon & Punai biasa & 1 & - & - & & $\mathrm{LC}$ & \\
\hline 12 & Columbidae & $\begin{array}{l}\text { Treron } \\
\text { vernans }\end{array}$ & $\begin{array}{l}\text { Pink-necked green- } \\
\text { pigeon }\end{array}$ & Punai laut & - & 2 & 7 & & $\mathrm{LC}$ & \\
\hline 13 & Cuculidae & $\begin{array}{l}\text { Centropus } \\
\text { sinensis }\end{array}$ & Greater Coucal & Burung Bubut & - & 3 & 3 & & $\mathrm{LC}$ & \\
\hline 14 & Dicaeidae & $\begin{array}{c}\text { Dicaeum } \\
\text { trigonostigma }\end{array}$ & $\begin{array}{l}\text { Orange-bellied } \\
\text { flowerpecker }\end{array}$ & Burung api-api & - & 1 & - & & $\mathrm{LC}$ & \\
\hline 15 & Estrildidae & $\begin{array}{l}\text { Lonchura } \\
\text { fuscans }\end{array}$ & Dusky munia & Burung pipit hitam & 2 & 1 & 7 & & $\mathrm{LC}$ & \\
\hline 16 & Estrildidae & $\begin{array}{l}\text { Lonchura } \\
\text { malacca }\end{array}$ & Chestnut munia & Burung pipit merah & - & - & 17 & & $\mathrm{LC}$ & \\
\hline 17 & Estrildidae & $\begin{array}{l}\text { Lonchura } \\
\text { punctulata }\end{array}$ & $\begin{array}{l}\text { Scaly-breasted } \\
\text { munia }\end{array}$ & Burung pipit hitam & - & - & 9 & & LC & \\
\hline 18 & Hirundinidae & $\begin{array}{l}\text { Hirundo } \\
\text { tahitica }\end{array}$ & Barn swallow & $\begin{array}{l}\text { Burung layang- } \\
\text { layang batu }\end{array}$ & 37 & 23 & 24 & & LC & \\
\hline 19 & Laniidae & Lanius schach & Long-tailed shrike & Burung pentet & - & - & 1 & & LC & \\
\hline 20 & Pachycephalidae & $\begin{array}{l}\text { Pachycephala } \\
\text { grisola }\end{array}$ & Mangrove whistler & $\begin{array}{c}\text { Burung kacial } \\
\text { bakau }\end{array}$ & 1 & - & - & & LC & \\
\hline 21 & Passeridae & $\begin{array}{c}\text { Passer } \\
\text { montanus }\end{array}$ & $\begin{array}{l}\text { Eurasia Tree } \\
\text { Sparow }\end{array}$ & Burung Gereja & 4 & 1 & - & & $\mathrm{LC}$ & \\
\hline 22 & Picidae & $\begin{array}{l}\text { Dinopium } \\
\text { javanense }\end{array}$ & Common flamebcak & $\begin{array}{c}\text { Pelatuk } \\
\text { bawang/besi }\end{array}$ & - & 2 & - & & $\mathrm{LC}$ & \\
\hline 23 & Picidae & $\begin{array}{l}\text { Picus } \\
\text { miniaceus }\end{array}$ & $\begin{array}{c}\text { Banded } \\
\text { woodpacker }\end{array}$ & $\begin{array}{l}\text { Pelatuk kepala } \\
\text { merah }\end{array}$ & - & 1 & - & & $\mathrm{LC}$ & \\
\hline 24 & Psittacidae & $\begin{array}{l}\text { Loriculus } \\
\text { galgulus }\end{array}$ & $\begin{array}{l}\text { Blue-crowned } \\
\text { hanging-parrot }\end{array}$ & Burung srindit & - & 2 & - & B & LC & \\
\hline 25 & Pycnonotidae & $\begin{array}{l}\text { Pycnonotus } \\
\text { aurigaster }\end{array}$ & $\begin{array}{l}\text { Sooty-Headed } \\
\text { Bulbul }\end{array}$ & Kutilang & 6 & 4 & 5 & & $\mathrm{LC}$ & \\
\hline 26 & Pycnonotidae & $\begin{array}{l}\text { Pycnonotus } \\
\text { goiavier }\end{array}$ & $\begin{array}{l}\text { Yellow-vented } \\
\text { bulbul }\end{array}$ & Burung amporok & 9 & 8 & 6 & & LC & \\
\hline 27 & Nectariniidae & $\begin{array}{l}\text { Anthreptes } \\
\text { malacensis }\end{array}$ & $\begin{array}{l}\text { Brown-throated } \\
\text { sunbird }\end{array}$ & Burung cuit kelapa & - & 8 & 2 & A & $\mathrm{LC}$ & \\
\hline 28 & Nectariniidae & $\begin{array}{l}\text { Nectarinia } \\
\text { calcostetha }\end{array}$ & $\begin{array}{l}\text { Copper-throated } \\
\text { sunbird }\end{array}$ & Burung cuit hitam & 5 & 1 & - & A & $\mathrm{LC}$ & \\
\hline 29 & Nectariniidae & $\begin{array}{l}\text { Nectarinia } \\
\text { jugularis }\end{array}$ & $\begin{array}{l}\text { Olive-Backed } \\
\text { Sunbird }\end{array}$ & Burung Cuit Madu & 6 & 6 & 2 & A & $\mathrm{LC}$ & \\
\hline 30 & Nectariniidae & $\begin{array}{l}\text { Nectarinia } \\
\text { sperata }\end{array}$ & $\begin{array}{l}\text { Purple-throated } \\
\text { sunbird }\end{array}$ & $\begin{array}{l}\text { Burung madu } \\
\text { pengantin }\end{array}$ & 4 & - & - & A & $\mathrm{LC}$ & \\
\hline 31 & Rallidae & $\begin{array}{l}\text { Amaurornis } \\
\text { phoenicurus }\end{array}$ & $\begin{array}{l}\text { White-breasted } \\
\text { waterhen }\end{array}$ & Keroa padi & - & - & 2 & & $\mathrm{LC}$ & \\
\hline 32 & Rhipiduridae & $\begin{array}{l}\text { Rhipidura } \\
\text { javanica }\end{array}$ & Pied fantail & Burung silat-silat & 6 & 5 & - & $\mathrm{AB}$ & LC & II \\
\hline 33 & Sturnidae & $\begin{array}{l}\text { Acridotheres } \\
\text { javanicus }\end{array}$ & Javan myna & Jalak biasa & - & 3 & - & & $\mathrm{LC}$ & \\
\hline
\end{tabular}




\begin{tabular}{|c|c|c|c|c|c|c|c|c|}
\hline 34 & Sylviidae & $\begin{array}{c}\text { Orthotomus } \\
\text { ruficeps }\end{array}$ & Ashy tailorbird & $\begin{array}{c}\text { Ceriak kepala } \\
\text { merah }\end{array}$ & 7 & 1 & - & $\mathrm{LC}$ \\
\hline 35 & Timaliidae & $\begin{array}{c}\text { Malacocincla } \\
\text { sepiarium }\end{array}$ & Horsfield's babbler & $\begin{array}{c}\text { Burung pelanduk } \\
\text { semak }\end{array}$ & - & 4 & - & LC \\
\hline
\end{tabular}

Hasil pengamatan di habitat mangrove, ditemukan sebanyak 18 jenis avifauna dari 15 family. Family yang mendominasi adalah Hirundinidae dan Pycnonotidae yaitu 37 individu dan 15 individu dalam rata-rata harian avifauna yang ditemukan. Tercatat 8 jenis avifauna yang dilindungi dalam status perlindungan yaitu (A. PP No.7 tahun 1999 dan B. PERMENLHK No. P.20 tahun 2018). Status perdagangan international menurut CITES (Convention on International Trade in Endangered Species of Wild Fauna and Flora) tercatat ada 2 jenis avifauna yang termasuk kedalam kategori Apendiks II (spesies yang tidak terancam kepunahan, tetapi mungkin terancam punah bila perdagangan terus berlanjut tanpa adanya pengaturan/berlebihan) yaitu Rhipidura javanica dan Haliastur indus. Kategori status konservasi terhadap spesies, mengacu pada IUCN (International Union for the Conservation of Nature and Natural Resources), yaitu keseluruhan dari 18 jenis tersebut dikategorikan Least concern (beresiko rendah).

Hasil pengamatan di habitat kebun ditemukan sebanyak 23 jenis avifauna dari 18 family. Family yang mendominasi adalah Hirundinidae dan Nectariniidae yaitu 23 individu dan 15 individu dalam rata-rata harian avifauna yang ditemukan. Tercatat 7 jenis avifauna yang dilindungi dalam status perlindungan, yaitu (A. PP No.7 tahun 1999 dan B. PERMENLHK No. P.20 tahun 2018). Status perdagangan international menurut CITES, tercatat ada 2 jenis avifauna, yang termasuk kedalam kategori Apendiks II yaitu Rhipidura javanica dan Haliastur indus. Kategori status konservasi terhadap spesies, mengacu pada IUCN, yaitu keseluruhan dari 23 jenis tersebut dikategorikan Least concern (beresiko rendah).

Hasil pengamatan di lokasi sawah, ditemukan sebanyak 17 jenis avifauna dari 11 family. Family yang mendominasi adalah family Hirundinidae dan Estrildidae yaitu 24 individu dan 33 individu dalam rata-rata harian avifauna yang ditemukan. Tercatat 4 jenis avifauna yang dilindungi dalam status perlindungan yaitu (A. PP No.7 tahun 1999 dan B. PERMENLHK No. P.20 tahun 2018). Status perdagangan international menurut CITES tercatat ada 2 jenis avifauna yang termasuk kedalam kategori Apendiks II yaitu Haliaeetus leucogaster dan Haliastur indus. Kategori status konservasi terhadap spesies, mengacu pada IUCN, yaitu keseluruhan dari 17 jenis tersebut dikategorikan Least concern (beresiko rendah).

Jenis-jenis avifauna dari ketiga habitat tersebut yang masuk kedalam daftar dilindungi menurut aturan PP No. 7 tahun 1999 tentang pengawetan jenis tumbuhan dan satwa yaitu Raja Udang (Todirhamphus chloris), Kuntul kerbau (Bubulcus ibis), Madu kelapa (Anthreptes malacensis), Madu bakau (Nectarinia calcostetha), Madu sriganti (Nectarinia jugularis), Madu pengantin (Nectarinia sperata). Menurut aturan PERMENLHK 
No. P.20 tahun 2018 tentang jenis tumbuhan dan satwa yang dilindungi yaitu Blekok sawah (Ardeola speciosa), Srindit melayu (Loriculus galgulus) dan satwa avifauna yang dilindungi dari kedua aturan tersebut adalah Elang laut dada putih (Haliaeetus leucogaster), Elang bondol (Haliastur indus) dan Kipasan belang (Rhipidura javanica). Artinya, jumlah dari satwa yang dilindungi, menandakan bahwa ketiga habitat masih mampu dalam menyediakan lingkungan yang aman dan nyaman bagi satwa-satwa tersebut, baik dalam mencari makan maupun untuk berkembang biak. Avifauna yang terdapat di kawasan tersebut dan termasuk dilindungi harus tetap dijaga

kelestariannya dan mengusahakan untuk memberikan ekosistem yang nyaman bagi avifauna tersebut.

\section{B. Struktur Jenis Avifauna Diurnal}

Struktur jenis avifauna diurnal yang terdapat di kawasan Mempawah Mangrove Park dan sekitarnya yaitu di tiga jenis habitat, mangrove, kebun campuran dan sawah yang telah dilakukan pengamatan pada waktu pagi, siang dan sore hari dapat diketahui berdasarkan hasil perhitungan dari Indeks dominansi, Indeks keanekaragaman, Indeks kemerataan, Indeks kesamaan jenis, Tingkat pertemuan dan Kepadatan relatif yang dapat dilihat dari tabel 3 berikut ini :

Tabel 3. Indeks Dominansi, Keanekaragaman Jenis, Kemerataan, dan Kesamaan Jenis (Dominance Index, Species Diversity, Evenness index and Similarity index)

\begin{tabular}{|c|c|c|c|c|c|}
\hline \multirow[b]{2}{*}{ Indeks } & \multicolumn{3}{|l|}{ Lokasi } & & \\
\hline & $\begin{array}{l}\text { Mangrove } \\
\text { (M) }\end{array}$ & $\begin{array}{l}\text { Kebun campuran } \\
(\mathrm{K})\end{array}$ & $\begin{array}{l}\text { Sawah } \\
\text { (S) }\end{array}$ & & \\
\hline Dominansi (C) & 0,40 & 0,10 & 0,13 & & \\
\hline Keanekaragaman jenis $(\mathrm{H})$ & 2,43 & 2,66 & 2,40 & & \\
\hline Kemerataan (E) & 0,84 & 0,85 & 0,85 & & \\
\hline Kesamaan jenis (IS) & & & & $\begin{array}{l}(\mathrm{M} / \mathrm{K}) \\
(\mathrm{M} / \mathrm{S}) \\
(\mathrm{S} / \mathrm{K})\end{array}$ & $\begin{array}{l}53,58 \% \\
38,49 \% \\
53,19 \%\end{array}$ \\
\hline
\end{tabular}

Indeks dominansi digunakan untuk mengetahui kekayaan spesies serta keseimbangan jumlah individu setiap spesies dalam ekosistem. Fachrul (2008), menyatakan bahwa indeks dominansi Simpson bernilai antara $0-1$, jika nilai $\mathrm{C}$ mendekati 0 berarti tidak terdapat jenis yang mendominasi jenis lainnya atau komunitas berada dalam kondisi stabil, sedangkan jika nilai $\mathrm{C}$ mendekati 1 berarti terdapat jenis yang mendominasi jenis lainya atau komunitas berada dalam kondisi tidak stabil karena terjadi tekanan ekologis. Hasil spesies-spesies yang mendominasi dari ketiga habitat yaitu mangrove, kebun dan sawah menunjukkan hasil perhitungan indeks dominansinya mendekati nol (0). Nilai dominansi untuk habitat mangrove adalah $\mathrm{C}=0,40$, habitat kebun dengan $\mathrm{C}=0,10$ dan habitat sawah dengan $\mathrm{C}=0,13$, sehingga dari 18 spesies yang ditemukan di mangrove, 23 spesies yang ditemukan di kebun dan 17 spesies yang ditemukan di sawah tidak ada jenis 
yang mendominasi jenis yang lain, artinya peranan spesies avifauna yang ditemukan pada ketiga habitat sama. Hal yang membuat tidak adanya avifauna yang mendominasi, bisa disebabkan dari beberapa faktor, salah satunya adalah faktor makanan, ketersediaan makanan yang cukup membuat spesies yang ada, tidak menciptakan persaingan dalam hal mencari makan.

Keanekaragaman jenis avifauna berbeda dari suatu tempat ke tempat lainnya tergantung pada kondisi lingkungan dan faktor yang berpengaruh. Menurut Shannon-wiener; Oki Hidayat (2013), kisaran atau kriteria keanekaragaman jenis $(\bar{H})$ antara 1-3. Kriteria nilai $\bar{H}<1$ berarti keanekaragaman rendah, jika $1<\bar{H}<3$ berarti keanekaragaman sedang dan jika $\bar{H}$ $>3$ berarti keanekaragaman tinggi. Hasil perhitungan indeks keanekaragaman jenis avifauna pada masing-masing lokasi, menunjukkan bahwa habitat mangrove memiliki nilai indeks $(\bar{H})=2,43$, habitat sawah dengan nilai indeks $(\bar{H})=2,40$ dan kebun memiliki nilai indeks keanekaragaman jenis yang lebih tinggi dengan nilai Indeks $(\bar{H})=2,66$. Nilai tersebut menunjukkan bahwa ketiga lokasi memiliki keanekaragaman dengan kriteria sedang. Hal ini dikarenakan beragam jenis vegetasi yang terdapat pada lokasi kebun memungkinkan untuk menyediakan daya dukung lingkungan yang mencukupi untuk avifauna tersebut hidup dan mencari makanan. Widodo (2009) memberikan pernyataan bahwa habitat yang kondisinya baik dan jauh dari gangguan manusia serta didalamnya mengandung bermacam- macam sumber pakan, memungkinkan memiliki jenis avifauna yang banyak.

Penelitian lainnya tentang keanekaragaman avifauna di Kawasan Mangrove sekitar di daerah Sungai bakau kecil dan Desa Peniti Luar Kabupaten Mempawah yang dilakukan oleh Angga (2015) adalah nilai Indeks keanekaragaman untuk lokasi Desa Peniti Luar yaitu 2,14 sedangkan untuk lokasi Desa Sungai Bakau Kecil yaitu 1,86. Perbandingan untuk hasilnya di lokasi Desa Peniti Luar mendekati dengan penelitian yang saya lakukan di MMP sedangkan untuk Sungai Bakau Kecil kurang, faktor yang menentukan bisa dari kondisi lingkungan sekitar, semakin tinggi nilai Indeks keanekaragaman berarti semakin beragam jenis yang terdapat pada komunitas tersebut.

Indeks kemerataan (E) dalam suatu habitat berkisar antara 0 -1, yaitu apabila 0 $<\mathrm{E} \leq 0,5$ maka komunitas dikatakan tertekan, apabila $0,5<\mathrm{E} \leq 0,75$ maka komunitas dikatakan labil, dan apabila nilai indeks kemerataan $0,75<\mathrm{E} \leq 1$ maka komunitas stabil, menurut Daget (1976); Solahudin (2003). Hasil perhitungan indeks kemerataan jenis avifauna pada masing-masing lokasi, yaitu pada lokasi mangrove indeks kemerataan (E) $=0,84$, di lokasi kebun indeks kemerataannya $(\mathrm{E})=0,85$ dan lokasi sawah memiliki indeks kemerataan $(\mathrm{E})=$ 0,85 . Berdasarkan nilai indeks kemerataan tersebut, maka pada ketiga habitat kelimpahannya termasuk merata atau termasuk dalam komunitas stabil. Kemerataan jenis yang rendah dapat disebabkan oleh berbagai macam faktor, 
yaitu : (a) adanya persaingan dalam pemanfaatan sumber daya yang ada. (b) adanya perburuan secara besar-besaran sehingga jenis dan jumlah individu avifauna semakin berkurang. (c) tidak dapat menyesuaikan diri pada lokasi yang baru. (Magurran 2004; Syahadat 2015).

Tingkat Pertemuan dilakukan untuk menghitung setiap spesies disuatu habitat dengan membagi jumlah avifauna yang tercatat setiap jenisnya dengan jumlah jam yang dihabiskan didalam pengamatan, memberikan gambaran avifauna perjam untuk setiap spesies. Informasi tambahan juga dapat diperoleh dengan menentukan tingkat pertemuan terpisah untuk setiap jenis habitat yang luas, misalnya seperti pada pengamatan ini yang dilakukan di lokasi hutan mangrove, kebun campuran dan sawah. Data tingkat pertemuan dapat dibagi menjadi kategori ordinal mentah kelimpahan (misalnya berlimpah, umum, sering, jarang dan langka). Kategori untuk tingkat pertemuan pengamatan ini adalah hasil modifikasi dari kategori dalam buku "Expedition Field Techniques Bird Surveys" dari Colin Bibby et al., yaitu untuk nilai $\leq 1,1$ kategori langka, nilai 1,2 - 22,2 kategori jarang, nilai 22,3 - 111,1 kategori sering, kategori 111,2 - 444,4 kategori umum dan nilai $>444,4$ kategori melimpah.

Hasil pengamatan yang dilakukan di tiga habitat yang berbeda yaitu hutan mangrove, kebun campuran dan sawah memiliki beberapa kesamaan jenis avifauna yang ditemukan. Indeks kesamaan jenis dapat digunakan untuk melihat kesamaan antara jenis avifauna pada setiap habitat yang berbeda. Indeks kesamaan jenis avifauna paling tinggi adalah antara habitat mangrove dengan kebun dengan persentase 53,58\%. Habitat sawah dengan kebun dengan persentase $53,19 \%$, habitat mangrove dengan sawah dengan persentase 38,49\%. Tinggi atau rendahnya dari nilai kesamaan jenis pada masing-masing lokasi pengamatan bisa disebabkan dari kondisi jenis vegetasi yang berbeda dan jenis makanan yang dimakan avifauna di suatu habitat, karena sebagian jenis avifauna ada yang memakan bagian dari tumbuh-tumbuhan, seperti biji-bijian, buah, nektar pada bunga serta ada beberapa spesies yang memakan serangga dan ikan. Menurut (Ardley 1984; Eko 2018) bahwa setiap spesies avifauna hanya memakan jenis makanan tertentu saja dan ia akan hidup nyaman pada kondisi lingkungan yang sesuai dengan dirinya tersebut.

\section{KESIMPULAN}

Berdasarkan dari hasil penelitian dan uraian pembahasan yang dilakukan pada tiga habitat di Mempawah Mangrove Park dan sekitarnya, yaitu di habitat mangrove, kebun campuran dan sawah, maka dapat ditarik kesimpulan sebagai berikut :

1. Keanekaragaman jenis avifauna yang ditemukan di habitat mangrove, kebun campuran dan sawah dijumpai sebanyak 35 jenis avifauna yang terdiri dari 24 family dengan total keseluruhannya sebanyak 305 individu. Pengamatan di lokasi mangrove tercatat sebanyak 18 jenis avifauna dengan ratarata total keseluruhan 117 individu yang termasuk kedalam 15 family. Lokasi kebun campuran tercatat sebanyak 22 jenis avifauna dengan rata- 
rata total keseluruhan 92 individu yang termasuk kedalam 18 family, serta pada lokasi sawah tercatat sebanyak 17 jenis avifauna dengan rata-rata total keseluruhan 96 individu yang termasuk kedalam 11 family.

2. Keanekaragaman jenis avifauna tertinggi yang dilihat dari nilai indeks keanekaragaman jenis berdasarkan indeks Shannon-wiener adalah di habitat kebun dengan nilai 2,66 yang menunjukkan bahwa habitat kebun memiliki keanekaragaman dengan kriteria sedang dengan nilai tertinggi setelah habitat mangrove dengan nilai 2,43 dan habitat sawah dengan nilai 2,40 .

\section{SARAN}

1. Perhatian khusus mengenai satwa avifauna di Mempawah Mangrove Park perlu untuk dilakukan, salah satunya dengan terus berupaya dalam menciptakan vegetasi sekitar, sebagai kebutuhan utama avifauna dalam berlindung, berkembang biak serta mencari makan.

2. Pemberitahuan kepada pihak pengunjung serta masyarakat sekitar tentang pentingnya perlindungan, bukan hanya terhadap vegetasi yang ada seperti mangrove, namun juga terhadap satwa-satwa yang mendiami kawasan tersebut seperti avifauna.

3. Penelitian jenis avifauna diurnal di kawasan Mempawah Mangrove Park dan sekitarnya perlu dilakukan secara berkala pada saat musim atau tahun yang akan datang, sehingga data avifauna di kawasan tersebut terus mendapat informasi data yang diperbarui.

\section{DAFTAR PUSTAKA}

Angga. 2015. Keragaman Jenis Burung Air Di Kawasan Hutan Mangrove Primer Dan Hutan Mangrove Hasil Reboisasi Di Kabupaten Mempawah. Protobiont 4:118-125.

Bibby C, Martin J, Stuart M. 2000. Expedition Field Techniques. Cambridge: Birdlife International.

Eko PH. 2018. Studi Keanekaragaman Jenis Burung Diurnal Di Seksi Pengelolaan Taman Nasional (Sptn) Wilayah iii Selimbau Taman Nasional Danau Sentarum Kabupaten Kapuas Hulu Provinsi Kalimantan Barat. Jurnal Hutan Lestari 6. 2 : 293-298.

Fachrul MF. 2008. Metode Sampling Bioekologi. PT Bumi Aksara. Jakarta.

MacKinnon JK, Phillipps K, Bas VB. 2010. Burung-burung di Sumatera, Jawa, Bali dan Kalimantan (Termasuk Sabah, Serawak dan Brunei Darussalam). Puslitbang Biologi LIPI. Bogor:Burung Indonesia.

Maya A. 2016. Keanekaragaman jenis burung di hutan rakyat Pekon Kelungu Kecamatan Kota Agung Kabupaten Tanggamus. Jurnal Sylva Lestari 4. 2:51-60.

Solahudin AM. 2003. Keanekaragaman Jenis Burung Air di Lebak Pampangn Kecamatan Pampangan Kabupaten Ogan Komering Ilir Sumatera Selatan. Jurusan Manajemen Hutan Fakultas Pertanian Universitas Lampung.

Syafrudin D. 2011. Jurnal Keanekaragaman Jenis Burung 
JURNAL HUTAN LESTARI (2019)

Vol. 7 (1) : 316 - 326

Pada beberapa Tipe Habitat Di Tambling Wildlife Nature Conservation (TWNC). Diakses tanggal 12 April 2012 pukul 01.20 Wib.

Syahadat F. 2015. Studi keanekaragaman jenis burung diurnal di Hutan Mangrove Pantai Air Mata Permai Kabupaten Ketapang. Jurnal Hutan Lestari. 3(1):21-29.

Widodo W. 2013. Kajian fauna burung sebagai indikator lingkungan di hutan Gunung Sawal, Kabupaten Ciamis, Jawa Barat. Prosiding Seminar Nasional $X$ Pendidikan Biologi FKIP UNS. FKIP Univ. Negeri Sebelas Maret Surakarta. Surakarta, 6 Juli 2013. 245-255 hlm.

Wisnubudi G. 2009. Penggunaan strata vegetasi oleh burung di Kawasan Wisata Taman Nasional Gunung Halimun-Salak. Jurnal Vis Vitalis. 2(2) : 41-49. 